\title{
LETTER FROM VIENNA.
}

\section{(From our own Correspondent.)}

Is order that the following outline of the medical societies in Vienna may be clear to a foreigner, some preliminary explanation is necessary.

Like the rest of the population, the medical fraternity in German Austria is split up into parties by nationality, religion, and political conviction. For very many years the medical profession in Vienna has been divided into two great groups: the Aryan and the Jew. To these two parties, who, though they quarrelled as occasion arose, agreed fairly well on the whole especially where questions affecting the common interests of the medical profession were concerned, there has been added since the Peace a third party-the eastern Jews from Poland and Galicia who have taken advantage of the political situation to settle in Vienna. Among them, as might be supposed from their origin, are numerous elements with an oriental bolshevist tendency, and also many who have not a very high standard of professional Morals. In view of all this, it is a very noteworthy manifestation of professional solidarity that, as I mentioned in my last letter, it has been possible to unite, with very few exceptions, all the doctors in Vienna in a comprehensive defence society-the Wirtschaftliche Organisation der Aerzte Wiens. To the benefits which have resulted from this union I have already alluded.

If we now turn to the activities of medical societies in Vienna, we have first to distinguish between those whose aims are purely scientific, and those which deal with medical politics and professional interests in the more material sense. Of the first series, the most important and oldest established is the Gesellschaft der Aerste, which is well known beyond the confines of Austria. Membership of this society is restricted to those who have done scientific work. Accordingly admission to the society, though now more easily attained than in the past, is limited to a relatively small number of men-teachers in the University, members of hospital staffs, and assistants in the various departments, as well as a few honorary and corresponding members. The Gesellschaft der Aerzte possesses premises of its own, the Billroth-haus, with a large lecture hall fully equipped with projection apparatus, in which its weekly scientific meetings, demonstrations of patients, etc., are held. In the building is also housed the valuable library which is the property of the society, and the editorial offices of the Wiener klinische Wochenschrift which belongs to the society. The subscription is fairly high, on account of the numerous advantages the society affords to its members. Candidates for 


\section{Letter from Vienna}

membership, who must be proposed and supported by six members, are elected annually at a general meeting.

As regards other scientific societies, almost every specialty has its own, in which, almost weekly, communications are read and demonstrations given. Admission to these special societies presents no difficulty, and the meetings, which are well attended, usually take place in the lecture rooms of the various special departments.

An old established society, at which scientific subjects are discussed, but which is chiefly concerned with the professional interests of its members, is the Wiener Medizinische Doktoren-Collegium, which in former times had a semi-official status. It maintained three benevolent institutions for its members-a widows and orphans society, a pensions institute, and a charity institute-and gave numerous grants to students and doctors. In pre-war days it was a wealthy body, but has been greatly impoverished by the depreciation of money in Austria. Two other benevolent societies for medical men and their dependents have also suffered from the same cause, for it is not feasible, medical incomes being what they are, to raise the subscriptions to such societies to a lure which will admit of adequate benefits being paid.

A very large association with branches all over the country, the membership of which is restricted to Aryans, is the Verein deutscher Aerzte in Oesterreich. Its objects are partly scientific and partly political; associated with it there is a savings bank which makes advances to members, and it publishes a paper, the Aerztliche Reform Zeitung. There are also in Vienna local unions which are sections of the Wirtschaftliche Organisation aforesaid, and form channels of communication between individual doctors and the President of the organisation. These local unions (Bezirkssektione) play a very important part in the doctor's daily work, because they act as agencies for the supplying of heating materials and other necessities of life which the doctors think necessary in their welfare work.

There are further various special medical societies-Jewish, Christian, musical, orchestral, and official, whose activities require no further mention.

Whether the truce with the Government and the parties in the National Assembly, to which I alluded in my last letter, will continue and culminate in an enduring peace, is not yet certain. The present Government does not seem to be lacking in good will towards the doctors. They have, for example, introduced a new Bill for regulating medical practice (Aerzte ordnung) in which the principal demands of the profession appear to be incorporated. It now remains to be seen whether the measure will pass the Chamber in a form acceptable to the medical profession. The question of the Profits tax (Erwerbs steuer) 


\section{Letter from Vienna}

is a very difficult one. This is a tax which must be paid, in addition to income tax, by every one who pursues any occupation for gain. As this tax pressed very heavily on the doctors, one of their demands was that they should be exempted from it. This the Government refused, on the ground that legislation would be required, but they have promised that the tax would be made less burdensome. As regards reform of medical education, here again the wishes of the doctors have been taken into account, though it must be admitted that on one point, a compulsory year of hospital work after the conclusion of the students' curriculum, there is no unanimity of opinion among the doctors themselves. The new Health Ministry is to be re-constituted in accordance with the wishes of the profession. 